\title{
Analysis of settlement prediction due to preloading and vertical drain applications on runway construction
}

\author{
Adriyati Meilani ${ }^{1}$, Rifa $^{\prime} i$ Ahmad $^{1,{ }^{*}}$ and Faris Fikri ${ }^{1}$ \\ ${ }^{1}$ Department of Civil and Environmental Engineering, Universitas Gadjah Mada, Yogyakarta, Indonesia
}

\begin{abstract}
Consolidation settlement is a general geotechnical problem particularly found in the area where is composed of soft soil. It is caused by the discharge of pore water pressure induced by the increase of stress in the soil mass. Construction of runway above soft soil requires analysis for stability related to the reduction of consolidation settlement and the recovery. This study aims to analyze the settlement comprehensively using empirical methods of Prefabricated Vertical Drains (PVD) and preloading installation. Preloading is a technique by which consolidation of soil can be achieved to a substantial amount before the imposition of actual construction load. According to soil investigation, the characteristic of the soil layer is clay soil, which has the potential to consolidation settlement. The result of the settlement analysis of the taxiway in the research area is from $33 \mathrm{~cm}$ to $214 \mathrm{~cm}$. It takes ten years for primary consolidation to reach a $90 \%$ degree of consolidation. However, in the Hansbo method of Prefabricated Vertical Drains (PVD) and preloading are applied, with triangular configurations in depth of 11 meters and duration for variation embankment spacing of $1 \mathrm{~m}$ is 79 days, $1.5 \mathrm{~m}$ is 202 days and $2 \mathrm{~m}$ is 390 days. The conclusion of efficient distance of PVD installation and preloading is spacing of $1 \mathrm{~m}$ with 79 days for primary consolidation.
\end{abstract}

\section{Introduction}

Consolidation is one of the primary methods for improvement of geotechnical properties of soil to make it suitable for construction of structure; one of them is Runway Construction in soft soil. Preloading or surcharge is probably the most widely used technique to accelerate the consolidation process and to strengthen the weak clayey soil in situ. The primary consolidation process may take quite a long time because of the low permeability of clay soils. Many improvement techniques have been developed to suit particular soil conditions. Preloading with Prefabricated vertical drains (PVDs) have been widely used in low permeability soft soil improvement [12, 11, 3].

Previously sand drains were used for acceleration of consolidation of soft soils. With the increasing use of polymer-based products and change in construction requirements, synthetic or polymer-based prefabricated vertical drains have replaced those drains to make the consolidation much faster and thereby, it has reduced the construction time to a great extent [1].

Preloading with vertical drains is a successful ground improvement technique, which involves the loading of the ground surface to induce most of the ultimate settlement. Usually, a surcharge load equal to or greater than the expected to accelerate consolidation with the aid of vertical drains [3].

In this paper, construction of runway above soft soil, require to be analysis for stability related to the reduction of consolidation settlement and recovery by improvement techniques is Prefabricated Vertical Drains (PVD) are a composite geosynthetic system consisting of an inner core and outer filter jacket and preloading with triangular configurations and variation embankment spacing of $1 \mathrm{~m}, 1.5 \mathrm{~m}$, and $2 \mathrm{~m}$.

\section{Literature Review}

\subsection{Soft Soil}

The classification of soils is determined based on the results of soil investigation. Clay is one type of finegrained soil with a grain diameter of $<0.002 \mathrm{~mm}$. Characteristics of soft soil or cohesive soil are high compression, low permeability coefficient, low shear force and low carrying capacity [3], defines soft soil with the following specifications:

a. Land Specific Gravity (Gs) ranges between 2.6 to 2.9;

b. Water content in saturated conditions reaches $90 \%$ to $120 \%$;

c. Liquid limit (LL) of more than $50 \%$;

d. The void ratio (e) reaches 2.5 to 3.2 ;

e. The permeability coefficient $(\mathrm{k})$ is very low or less than $10-6 \mathrm{~cm} / \mathrm{sec}$.

\subsection{Consolidation Settlement Primer}

Consolidation primer is also called the hydrodynamic consolidation phase. The process of degradation in this 
phase is determined by the properties of the soil, which affect the speed of exposure of pore water out of the soil cavities due to loading. The type of consolidation settlement in which the increase in vertical effectivestress causes the individual particles of the soil to rearrange into a tighter packing is known as consolidation settlement.

\subsection{Consolidation Coefficient}

Effect of vertical drainage of natural subsoil and the effect of radial drainage due to the existence of PVD. Under this condition, the PVD improved subsoil can be analyzed in the same way as the unimproved case. This equivalent value of vertical hydraulic conductivity $\mathrm{k}_{\mathrm{v}}$ is derived based on the equal average degree of consolidation under the $1 \mathrm{D}$ condition.

\subsection{Prefabricated Vertical Drain (PVD)}

The PVD is a synthetic drainage element comprised of a drainage core wrapped in a geotextile filter [11]. PVD is a plastic sheet for long and pocketed vertical drainage, which is a combination of high mechanical strength polypropylene core material [8], shown in Fig 1.

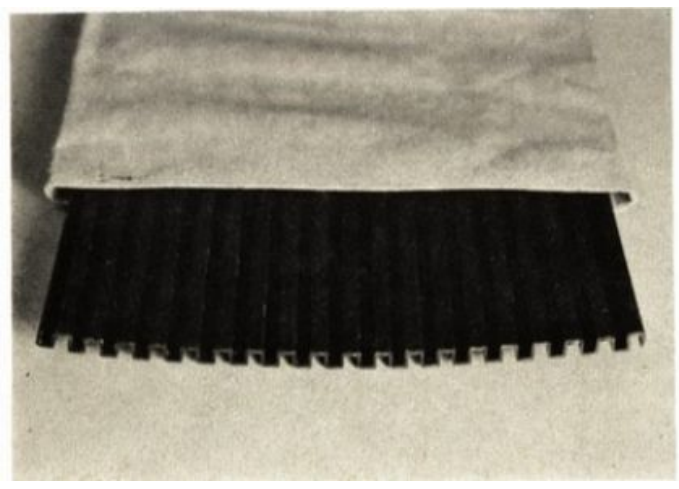

Fig. 1. Typical of PVD [9]

Prefabricated vertical drains (PVD) are commonly used to decrease the drainage path within soft soils to accelerate the time of primary consolidation [10].

The formulation of radial consolidation around a vertical sand drain system is an extension of the onedimensional Consolidation theory [6]. Presented a more comprehensive solution to the problem of radial consolidation via drain wells, where two extreme cases of free strain and equal strain were studied to show that the average consolidation obtained in these cases is nearly the same [2].

\subsection{Diameter of Rectangular Vertical Drain}

Most PVD are produced in the factory in rectangular cross-section to facilitate storage, transportation and installation. However, in the conventional theory, the
PVD is assumed to consolidate in a radial direction. So, for design purposes, the width (w) and the thickness (h) of the PVD need to be converted into an equivalent circular with a diameter of $d_{w}$. Many researchers proposed the conversion equation, but their results are almost similar. Vertical drainage with a triangular pattern usually provides more uniform consolidation (see Fig 2).

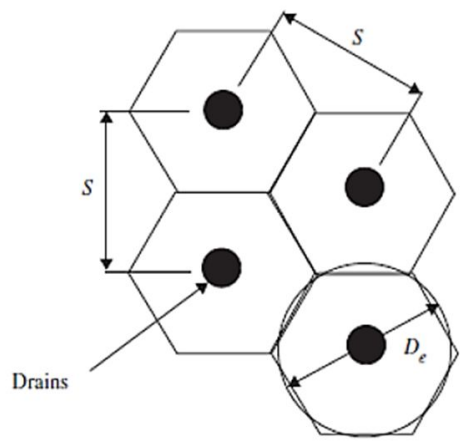

Fig. 2. PVD Triangle Configuration $[1,10]$

\subsection{Preloading in Prefabricated Vertical Drain (PVD)}

The combination of the preloading method and prefabricated vertical drains (PVD) is one method to accelerate the consolidation process. The combination of this method is giving the initial load in the form of preloading on clay, which has been given a vertical drainage system in the form of PVD illustrated (see Fig. 3).

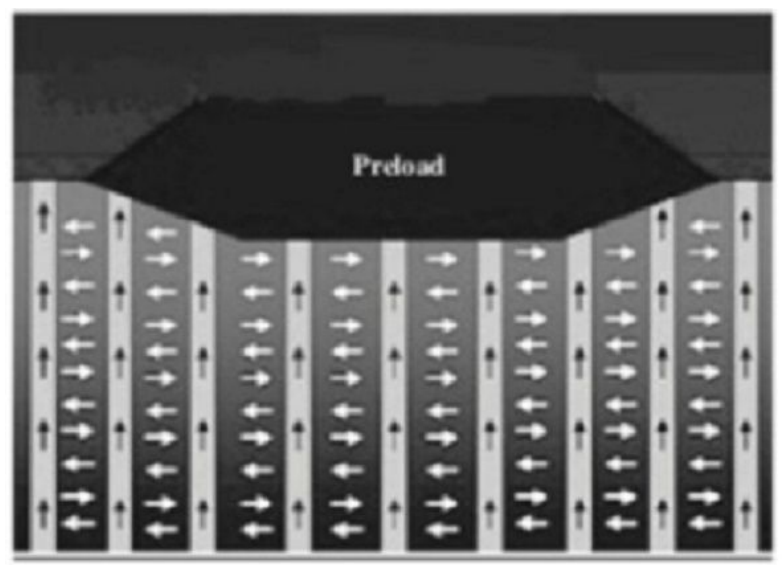

Fig. 3. Illustration of Combined PVD and Preloading [7]

Some functions of using PVD include:

a. Speed up the primary consolidation process.

b. Reducing the surcharge load needed to get the same results with consolidation for a certain period of times,

c. Speed up the addition of soil shear strength due to soft soil consolidation. 


\section{Method}

\subsection{Soil Profile}

A total of 58 test deep-borings and 160 laboratory test were completed for this project, all data will certainly not be used, and data which is relevant to the research will be selected. Based on the results of observations on the drill data and laboratory analysis, the drill point data used to describe the soil layer at the study site is 3 points.

According to the soil investigation data, the research area is dominated by clayey in the surface less than 12 $\mathrm{m}$, and the author used standards interpreting for stratigraphic analysis is ASTM D1586-11 and SNI 4153-2008.

\subsection{Data}

Based on the results of observations on the drill data and laboratory analysis, the drill point data used to describe the soil layer at the study site were 3 locations. The results of the interpretation carried out by considering the description of the soil and the results of drilling and the N-SPT value can be described as the soil conditions in the PVD area (see Fig. 4).

Soil parameters are obtained from N-SPT and Laboratory tests. The N-SPT test was carried out to understand the soil engineering properties, which will then be used to analyze soil degradation and vertical drainage (see Table 1).

Table 1. Soil Parameters

\begin{tabular}{|c|c|c|c|}
\hline Parameter & Symbol & Unit & Layers \\
\hline$\overline{\text { Depth }}$ & - & $\mathrm{m}$ & $\begin{array}{c}0,00- \\
10,00\end{array}$ \\
\hline Thickness & - & $\mathrm{m}$ & 10 \\
\hline Material Model & - & - & $\begin{array}{l}\text { Mohr- } \\
\text { Coulomb }\end{array}$ \\
\hline Type model & - & - & undrained \\
\hline Wet volume weight & $\gamma_{\mathrm{b}}$ & $\mathrm{kN} / \mathrm{m}^{3}$ & 17.36 \\
\hline $\begin{array}{l}\text { Weight of wet } \\
\text { saturated volume }\end{array}$ & $\gamma_{\text {sat }}$ & $\mathrm{kN} / \mathrm{m}^{3}$ & 18 \\
\hline Vertical permeability & $\mathrm{k}_{\mathrm{v}}$ & $\mathrm{m} /$ days & 0.0864 \\
\hline Modulus of elasticity & $\mathrm{E}$ & $\mathrm{kN} / \mathrm{m}^{2}$ & 800 \\
\hline Poisson ratio & $\mathrm{v}$ & - & 0.3 \\
\hline $\begin{array}{l}\text { Cohesion in } \\
\text { undrained conditions }\end{array}$ & $\mathrm{c}_{\mathrm{u}}$ & $\mathrm{kN} / \mathrm{m}^{2}$ & 37.1 \\
\hline Friction angle & $\varphi$ & o & 10,8 \\
\hline Volume coefficient & $\mathrm{m}_{\mathrm{v}}$ & $\mathrm{m}^{2} / \mathrm{kN}$ & 0.002 \\
\hline
\end{tabular}

\subsection{Analysis Consolidation}

Solution based on equal vertical strain hypothesis was developed on the assumption that horizontal sections remain horizontal throughout the consolidation process [7].

$$
\mathrm{S}_{\mathrm{c}}=\frac{\mathrm{C}_{\mathrm{c}}}{1+\mathrm{e}_{0}} \mathrm{H} \log \frac{\mathrm{p}_{\mathrm{o}}^{\prime}+\Delta \mathrm{p}}{\mathrm{p}_{\mathrm{o}}^{\prime}}
$$

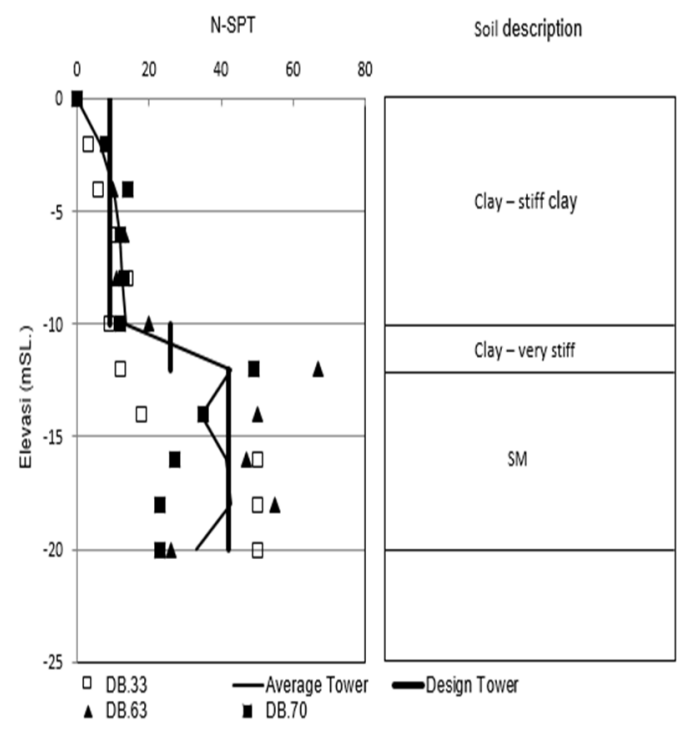

Fig. 4. Soil properties and profile

where $\mathrm{C}_{\mathrm{c}}$ is compression index; $\mathrm{e}_{\mathrm{o}}$ is void ratio; $\mathrm{p}_{0}{ }^{\prime}$ is initial effective overburden pressure and $\Delta_{\mathrm{p}}$ is additional stress due to the embankment load.

According to the soil parameter shown in Table 1, the vertical consolidation coefficient value is $\mathrm{m}_{\mathrm{v}}$ obtained where the volume change coefficient is the ratio of changes in volume per unit to the addition of effective stress $\left(\mathrm{cm}^{2} / \mathrm{kg}, \mathrm{m}^{2} / \mathrm{kN}\right)$. The higher the value of $\mathrm{m}_{\mathrm{v}}$ the more soft soil. The vertical consolidation coefficient value where the volume change coefficient ( $\mathrm{m}_{\mathrm{v}}$ ) is obtained the ratio of changes in volume per unit to the addition of effective stress for $\mathrm{U}=90 \%$ used $\mathrm{T}_{\mathrm{v}}=$ 0,848 .

$$
\mathrm{c}_{\mathrm{v}}=\frac{0,848 \mathrm{H}_{\mathrm{t}}}{\mathrm{t}_{90}}
$$

Where $c_{v}$ is the vertical coefficient of consolidations $\left(\mathrm{m}^{2} /\right.$ day); $\mathrm{H}_{\mathrm{t}}(\mathrm{m})$ is the initial soil thickness.

Table 2. Coefficient of Consolidations

\begin{tabular}{cccc}
\hline Layers & $\begin{array}{c}\gamma_{w} \\
(\mathrm{kN} / \mathrm{m} 3)\end{array}$ & $\begin{array}{c}\mathrm{m}_{\mathrm{v}} \\
(\mathrm{m} 2 / \mathrm{kN})\end{array}$ & $\begin{array}{c}\mathrm{c}_{\mathrm{v}} \\
(\mathrm{m} 2 / \text { days })\end{array}$ \\
\hline 1 & 9,81 & 0,002 & 4,40 \\
2 & 9,81 & 0,1 & 3,21 \\
3 & 9,81 & 0,3 & 1,07 \\
\hline
\end{tabular}

The pore water pressure into vertical drainage is axisymmetric. Analytical modeling of radial flow towards vertical drainage consists of cylindrical soil surrounding a vertical drainage with simple boundary conditions. Table 3 is The equivalent consolidation 
coefficient calculation from the axisymmetric to the plane strain model.

Table 3. The Equivalent Coefficient of Calculation

\begin{tabular}{ccccc}
\hline $\begin{array}{c}\text { Depth } \\
(\mathrm{m})\end{array}$ & $\begin{array}{c}\text { hi } \\
(\mathrm{m})\end{array}$ & $\begin{array}{c}\mathrm{c}_{\mathrm{vi}} \\
(\mathrm{m} 2 / \text { years })\end{array}$ & $\sqrt{c_{v i}}$ & $\frac{h_{i}}{\sqrt{c_{v i}}}$ \\
\hline $\begin{array}{c}0,00- \\
10,00\end{array}$ & 10 & 4,40 & 2,10 & 4,77 \\
$\begin{array}{c}10,00- \\
12,00\end{array}$ & 2 & 3,21 & 1,79 & 1,12 \\
$12,00-$ & 8 & 1,07 & 1,04 & 7,73 \\
20,00 & & & & \\
\hline$\Sigma$ & 20 & 8,69 & & 13,61 \\
\hline
\end{tabular}

$\mathrm{c}_{\mathrm{v}}$ ekuivalen $=\left(\frac{20}{13,61}\right)^{2}=2,159 \mathrm{~m}^{2} /$ years

The consolidated has a thickness of $20 \mathrm{~m}$, with a consolidated coefficient value presented in Table 3.

\subsection{Preloading Method}

The height of the embankment is obtained from the results of the trial by considering the decrease in soil at the time of stockpiling. The load planned for location AA is the living load and the building load of each, which is equivalent to the burden of embankment. The volume of heap soil weight is $17.36 \mathrm{kN} / \mathrm{m}^{2}$ while for pavement loads and preloading a total of $25.6 \mathrm{kN} / \mathrm{m}^{2}$.

Embankment height planning needs to take into account immediate settlement and decrease consolidation so that the heap height can reach the plan elevation. In a large loading area, the immediate settlement is very small, so that there is no immediate decline. Trial height of $2.0 \mathrm{~m}$ to $3.8 \mathrm{~m}$ high pile height was conducted to determine the effective heap height by taking into account consolidation. The planned load for the construction area is the living load and building load of $15 \mathrm{kN} / \mathrm{m}^{2}$ and $25.6 \mathrm{kN} / \mathrm{m}^{2}$, respectively, which are equivalent to embankment loads.

The weight value of the landfill volume is 17.36 $\mathrm{kN} / \mathrm{m}^{3}$, then the living load is equivalent to a heap as high as $2.28 \mathrm{~m}$ and the building load is equivalent to a heap as high as $1.65 \mathrm{~m}$. In repairing soil using PVD, the sand blanket is used as $0.6 \mathrm{~m}$ thick horizontal drainage.

\subsection{Prefabricated Vertical Drain (PVD)}

The design of vertical drainage assuming ideal conditions do not take into account the effects of disruption and drainage resistance and only take into account the distance factor between vertical drainage, with distance variations $1 \mathrm{~m}, 1.5 \mathrm{~m}$ and $2 \mathrm{~m}$. The result of the analysis shows in Table 4.

$$
\mathrm{F}(\mathrm{n})=\ln (\mathrm{n})-0,75
$$

Where $F_{n}$ is drain the distance factor;

$$
\mathrm{n}=\frac{\mathrm{D}}{\mathrm{d}_{\mathrm{w}}}=\frac{\mathrm{r}_{\mathrm{e}}}{\mathrm{r}_{\mathrm{w}}}
$$

The following typical equation [5] can be used to determine the equivalent drain diameter.

$$
\mathrm{d}_{\mathrm{w}}=\frac{2(\mathrm{w}+\mathrm{h})}{\pi}
$$

Where $r_{e}=D / 2$ is cylinder radius effect vertical drainage; $r_{\mathrm{e}}$ is cylinder radius effect vertical drainage; $\mathrm{r}_{\mathrm{w}}=\mathrm{d}_{\mathrm{w}} / 2$ is vertical drainage radius; [2] suggested of $\mathrm{U}_{\mathrm{h}}$ and $\mathrm{T}_{\mathrm{h}}$

Table 4. Factor Between Vertical Drainage

\begin{tabular}{cccccc}
\hline $\begin{array}{c}\mathrm{S} \\
(\mathrm{m})\end{array}$ & $\begin{array}{c}\mathrm{Cv} \\
\left(\mathrm{m}^{2} / \mathrm{th}\right)\end{array}$ & $\begin{array}{c}\mathrm{D} \\
(\mathrm{m})\end{array}$ & $\mathrm{dw}$ & $\mathrm{n}$ & $\mathrm{F}(\mathrm{n})$ \\
\hline 1.00 & 4.40 & 1.05 & & 20.39 & 3.01 \\
1.50 & 4.40 & 1.58 & 0.05 & 30.58 & 3.42 \\
2.00 & 4.40 & 2.10 & & 40.78 & 3.71 \\
\hline
\end{tabular}

The permeability coefficient can be solved by,

$$
\mathrm{n}=\frac{\mathrm{D}}{\mathrm{d}_{\mathrm{w}}}=\frac{1,05}{0,05}=21
$$

Calculation of consolidation time is solve using equations (Hansbo,1979) for the degree of consolidation horizontal $\left(\mathrm{U}_{\mathrm{h}}\right)=90 \%$,

$$
\mathrm{t}=\frac{\mathrm{D}^{2}}{8 \mathrm{C}_{\mathrm{h}}} \mathrm{F}(\mathrm{n}) \ln \left(\frac{1}{1-\mathrm{U}_{\mathrm{h}}}\right)
$$

Where $c_{h}\left(\mathrm{~m}^{2} /\right.$ day $)$ is the vertical coefficient of consolidations; $\mathrm{U}_{\mathrm{h}}$ is the average degree of consolidation due to radial flow calculated; $\mathrm{D}$ is diameter; $\mathrm{n}$ is permeability coefficient.

Table 5. Time for Soil Consolidation

\begin{tabular}{cccc}
\hline $\begin{array}{c}\mathrm{S} \\
(\mathrm{m})\end{array}$ & $\begin{array}{c}\mathrm{Uh} \\
(\%)\end{array}$ & $\begin{array}{c}\mathrm{t} \\
\text { (years) }\end{array}$ & $\begin{array}{c}\mathrm{t} \\
\text { (days) }\end{array}$ \\
\hline 1 & 0.9 & 0.22 & 79.36 \\
1.5 & 0.9 & 0.56 & 202.59 \\
2 & 0.9 & 1.07 & 390.44 \\
\hline This
\end{tabular}
comprehensively due to Prefabricated Vertical Drains (PVD) and preloading installation using empirical methods. (see Table 5).

Primary consolidation generally takes a very long time and even takes years to reach a $90 \%$ degree of consolidation, considering the vertical and radial consolidation effects, is proposed by [7].

$$
\mathrm{U}=1-\left(1-\mathrm{U}_{\mathrm{v}}\right)\left(1-\mathrm{U}_{\mathrm{h}}\right)
$$

Where $\mathrm{U}_{\mathrm{v}}=$ average degree of consolidation due to vertical flow; and $U_{h}=$ average degree of consolidation due to radial flow calculated $[2,10,4]$. The results are presented in Table 6. 
Table 6. Result

\begin{tabular}{|c|c|c|c|c|}
\hline Parameter & $\begin{array}{c}\text { Tanpa } \\
\text { Perbaika } \\
\text { n Tanah }\end{array}$ & $\mathrm{S}=1 \mathrm{~m}$ & $\mathrm{~S}=1,5 \mathrm{~m}$ & $\mathrm{~S}=2 \mathrm{~m}$ \\
\hline $\mathrm{H}_{\mathrm{s}}(\mathrm{m})$ & 1.88 & 1.88 & 1.88 & 1.88 \\
\hline $\mathrm{H}_{1}(\mathrm{~m})$ & 1.38 & 1.38 & 1.38 & 1.38 \\
\hline $\mathrm{S}_{\mathrm{i}}(\mathrm{m})$ & 0.1 & 0.10 & 0.10 & 0.10 \\
\hline $\mathrm{S}_{\mathrm{c}}(\mathrm{m})$ & 0.78 & 0.84 & 0.85 & 0.85 \\
\hline $\mathrm{U}(\%)$ & 90 & 90 & 90 & 90 \\
\hline $\mathrm{TV}$ & 0.11 & 0.13 & 0.13 & 0.13 \\
\hline $\mathrm{t}$ (tahun) & 209 & 79 & 204 & 393 \\
\hline $\mathrm{H}_{\text {tot }}(\mathrm{m})$ & 4.15 & 4.20 & 4.21 & 4.21 \\
\hline Dw (m) & - & 0.05 & 0.05 & 0.05 \\
\hline $\mathrm{S} \max (\mathrm{m})$ & - & 0.10 & 0.10 & 0.10 \\
\hline $\mathrm{t}(\mathrm{m})$ & - & 0.22 & 0.56 & 1.08 \\
\hline $\mathrm{t}(\mathrm{m})$ & - & 80 & 204 & 393 \\
\hline $\begin{array}{l}\text { Average of } \mathrm{Cv} \\
\left(\mathrm{m}^{2} / \text { years }\right)\end{array}$ & - & 4.40 & 4.40 & 4.40 \\
\hline $\mathrm{Sc}(\mathrm{m})$ & - & 0.84 & 0.85 & 0.85 \\
\hline Uh lap & - & 0.88 & 0.88 & 0.88 \\
\hline $\mathrm{Th}$ & - & 0.88 & 0.99 & 1.07 \\
\hline $\mathrm{D}(\mathrm{m})$ & - & 1.05 & 1.58 & 2.10 \\
\hline $\mathrm{S}(\mathrm{m})$ & - & 1.00 & 1.50 & 2.00 \\
\hline Fn & - & 3.04 & 3.45 & 3.74 \\
\hline
\end{tabular}

\section{Conclusions}

1. Based on soil coating conditions in the study area, the consolidation time of $90 \%$ was achieved at a duration of 209 days with a decrease due to the consolidation of $0.788 \mathrm{~m}$.
2. Soil improvement using PVD with Mohr Coulomb's collapse criteria to achieve a consolidation time of $90 \%$ proves that the variation in distance of $1 \mathrm{~m}$ PVD results in a shorter time compared to variations in the distance of $1.5 \mathrm{~m}$ and $2 \mathrm{~m}$, which only takes 79 days. The percentage effect of fixing soil using PVD and not using PVD on time and the consolidation process shortens the time to 130 days.

\section{References}

1. A. K. Bhattacharya \& A. Basack, Geotechnical Conference, H-029 (2011)

2. A.R Barron, ASCE, 2346, 718-754, (1948)

3. B. Indraratna, I. Sathananthan, C. Rujikiatkamjorn \& S.A. Balasubramaniam. Int. J. Geomech, 10.1061, (2005)

4. B. M. Das. Principles of Geotechnical Engineering. (1995). Erlangga

5. J.J. Rixner, R.S Kraemer \& D.A Smith. Prefabricated vertical drains. Federal Highway Administration, Washington, I. D.C.Rep. No.FHWA/RD-86/168, (1986)

6. K. Terzaghi. Theoretical Soil Mechanics. (1943). New York. John Willey \& Sons, inc

7. K.W. K. Lau \& W. J Cowland, Adv. Transport. and Geoenviron. Geotechnical Special Publication 103, $140-161$ (2000)

8. Kjellman. Proc. 2nd ICSMFE, 2, 302-305, (1948)

9. N. Carrillo. J. Mathematics Physicals, 21(1), 1-5, (1942)

10. S.A. Sukla \& Kambekar A R 2013 Working Of Prefabricated Vertical Drain - A Case Study. IJIRSET, 2, (2003)

11. S. Hansbo. Ground Engineering, 12(5), 16-18, 21, (1979)

12. T.D. Bergado, A.S. Balasubramaniam, J.R. Fannin \& D.R. Holtz, Can.Geotech. J., 39(2), 304-315, (2002) 